\title{
Investigating Historical Abuses
}

\author{
An Applied History Perspective on Intercountry Adoption in the Netherlands, \\ 195os-Present
}

\author{
Yannick Balk | ORCID: 0000-0003-0723-2309 \\ Utrecht University, Utrecht, The Netherlands \\ Corresponding author \\ y.s.a.balk@outlook.com
}

Georg Frerks | ORCID: 0000-0001-8036-8064

Utrecht University, Utrecht, The Netherlands

g.frerks@uu.nl
Beatrice de Graaf | ORCID: 0000-0003-1592-935X
Utrecht University, Utrecht, The Netherlands
b.a.degraaf@uu.nl

Received September 30, 2021 | Accepted January 25, 2022 |

Published online February 16, 2022

\begin{abstract}
This article investigates the phenomenon and practice of intercountry adoption from a historical perspective by using applied history methods. In particular, we employed the method of historicizing current concerns, such as the notion of abuses, and contextualizing them in history. With these methods, we contributed to the Dutch governmental assessment and evaluation of intercountry adoption, indicating that our findings (as laid down in the official report) need to be translated into revised governmental policies. In this paper, we describe how we applied our historicizing methods to intercountry adoption abuses by providing a narrative and genealogy of the topic. We also discuss the pitfalls and merits of conducting historical research into practices that are now considered immoral or unjust, but were long standard practice after intercountry adoption started in the Netherlands. In this way, we also contribute to the ongoing discussion on doing historical research in highly politicized contexts, where the danger of contributing to the 'blame game' often lies in wait.
\end{abstract}




\section{Keywords}

intercountry adoption - abuses - applied history - government inquiry-policymaking

\section{Introduction}

On 8 February 2021, the Committee Investigating Intercountry Adoption (CIIA) published its long-awaited report. In the report, the cIIA presented its findings about the long history of the Dutch government's policy on intercountry adoption and possible abuses of that policy. The report immediately made headlines and came as quite a shock to many within Dutch politics and wider society. It was fully adopted by the government, which immediately suspended the practice of intercountry adoption. ${ }^{1}$ To others, this political decision came as no surprise, since the cIIA drew firm conclusions about the government's role and responsibilities with regard to abuses that had already been known and reported on in past decades. The cila however found that abuses were not glitches within the system, but were severe, systemic and widespread. And not only in the early stages, in the 1950s-196os, but up until the present day. ${ }^{2}$

This article describes the establishment, working and findings of the CIIA with regard to intercountry adoption abuses. It demonstrates how historical analysis can (and should) play a role in reflecting on and improving policymaking. Moreover, in this particular research, reflection on and the improvement of

1 Rapport Commissie Onderzoek Interlandelijke Adoptie [Report of the Committee Investigating Intercountry Adoption, CIIA] (The Hague, February 2021). An English summary, including the report's conclusions and recommendations can be downloaded at: https://www.government .nl/topics/adoption/documents/reports/2021/02/o8/summary-consideration-analysis-concl usions-recommendations (accessed January 25, 2022). For international press coverage, see "Dutch freeze international adoptions after abuses uncovered." Reuters, February 8, 2021; C. Moses, "Netherlands Halts Adoptions from Abroad After Exposing Past Abuses." New York Times, February 9, 2021.

2 It is a matter of scholarly debate when intercountry adoption in the Netherlands started exactly. Though most sources generally point to the post-wwiI period (late 1940s-195os), critical adoption and postcolonial scholars have highlighted earlier instances of removal of indigenous children from their families and, hence, much longer adoption genealogies than only those starting the in 195os. Wesseling, for example, documents the reallocation of children to children's homes or Dutch families the 189 os in the Dutch East Indies (Indonesia) under the banner of 'Ethical Policy'. Similar actions transpired in former French and British colonies. See L. Wesseling, "Creating Historical Genealogies for Intercountry Adoption." Adoption \& Culture 6 (1) (2018), 30-32. 
policymaking hinged on the suspicion of abuse. That makes historical research both more challenging and more relevant: how can we study abuses through time? How do we historicize such a normatively-charged notion?

In this paper, we will first present our research design. Coming from the field of applied history, we show how it is indeed possible to trace abuses through time, by developing a research question and approach that do justice to both present day normative questions and historical norms and standards. Second, we link our research design to the state of the art in academic literature on intercountry adoption. Since research into adoption was never a prerogative of historians but was carried out predominantly by social scientists, we will also demonstrate how a historicizing approach as such can be of added value to adoption studies by other disciplines. Third, we present and analyse our findings based on our research in different countries and archives and summarize the findings established by the CIIA. We conclude with a response to the main questions of this article: how can the notion of 'abuses' in intercountry adoption be historicized, what are the challenges and pitfalls of identifying past abuses, and what is the added value of historians in contributing to large-scale governmental inquiries?

The term 'abuses' is notoriously vague and fluid. How can such a normative and abstract category be rendered tangible; how can it be defined in such a way that it can be investigated adequately? Present day abuses can be investigated by subjecting them to legal scrutiny, to laws and international conventions, conceptual or definitional categories or ethical standards—although these are still variegated, fluid and dependent on context and place. Past abuses are even harder to identify and pin down. Such efforts will always elicit protests that the past cannot be judged from the perspective of contemporary biases. Within the CIIA this dilemma caused us many headaches. Ultimately, we decided to investigate adoption abuses by 'historicizing' them: viewing abuses within their own context in place and time, including within existing norms, values and available alternatives, and identifying the prevailing standards and assessments at the time. By historicizing adoption abuses, this article establishes an explicit link to applied history. ${ }^{3}$

3 H. Kaal and J. van Lottum, "Editorial." Journal of Applied History 1 (2019), 1-3. 
Applied history is the art of connecting the past with the present, studying past cases, patterns and developments, and asking ourselves questions that may still bear on today's issues. Applied history is at the same time an approach, a series of methods to make this connection; for example by drawing comparisons, by making analogies, by pointing to failure paths, or by highlighting long-term trends. ${ }^{4}$ In our research we apply a historicizing approach on a methodological plane by tracing abuses through time and comparing across regions, and on an analytical plane by conceptualizing abuse and producing generic insights on the way the system of intercountry adoption operated over the years, which vectors drove the system and how this changed over time. Conceptually speaking, such a historicizing approach means that adoption abuses have been investigated in two ways: as actions in violation of national and international laws and regulations and as actions not in conflict with such regulations but which were considered ethically irresponsible by contemporaries at the time itself. ${ }^{5}$ This conceptual duality takes into account the legislation applicable at the time and social views on adoption. By historicizing abuses in this fashion, both methodologically and conceptually, we aim to avoid fundamental pitfalls such as hindsight bias, without in turn falling into the trap of condoning or putting abuses in too mild a perspective.

The first category of abuses (legislation and regulations) comprises, for example, the forging of adoption papers or child theft. Abuses that fall in the second category (ethically irresponsible actions) include taking advantage of poverty in developing countries, giving up children under false pretenses or under pressure, or maintaining a lack of transparency in adoption documents and archives. It is important to note that, while various types of abuse can be identified, they usually take place in conjunction with one another: child trafficking, for example, is almost always accompanied by document forgery, bribery, corruption and profiteering.

The next step in applying such a historicizing approach is to apply it not only to individual acts of adoption but to the system as a whole. In this article, and in the cira's overarching investigation into abuses, the focus lies on the system of intercountry adoption. The adoption system is defined as the body of laws and regulations, government agencies and private organizations

4 B. de Graaf, L. Jensen, R. Knoeff, and C. Santing, "Wicked problems en de noodzaak van een diepe blik." https://www.historici.nl/aan-de-slag-een-manifest-voor-applied-history/?type=b ijdrage, May 13, 2020 (accessed January 25, 2022); M. MacMillan, The Uses and Abuses of History (Toronto: Penguin, 2008); cited in C. Colvin and P. Winfree, "Applied History, Applied Economics, and Economic History." Journal of Applied History 1 (2019), 28-41.

5 Report CIIA, 10-11. 
involved in intercountry adoption. This system definition has been chosen because it allows investigation of the roles, responsibilities and actions of all parties involved (government, private individuals, and others) in both sending and receiving countries and thereby reveal the underlying mechanisms of the system.

The definition of intercountry adoption (also known as international or transnational adoption) is: the legal adoption of a child from abroad that is not one's own offspring. The adoption process creates a permanent, legally established family relationship between the adoptive parents and the child. Adoption in a more general sense can be viewed as centuries-old. Think, for example, of the "adoptive emperors" in Roman Antiquity. Yet, these historical practices differ fundamentally from the phenomenon of intercountry adoption we know today. ${ }^{6}$ Intercountry adoption as a formal and legal category is a relatively recent phenomenon that emerged after World War II. ${ }^{7}$

The final step in applying our historicizing approach is locating the research data. This was predominantly done in archives, but the archival material was complemented by secondary sources covering the historical period, and keyperson and expert interviews both in the Netherlands and abroad. For this article we mainly focus on the archival aspect of the collected data. The archival research took place in more than a dozen archives at governmental departments and private parties. For the government, most of the relevant archives were located within the Ministry of Justice and Security and its related institutions, such as the Child Care and Protection Board [In Dutch: Raad voor de Kinderbescherming], the Immigration and Naturalization Service [Immigratieen Naturalisatiedienst (IND)], the Immigration Police, and the Public Prosecutor's Office [Openbaar Ministerie]. We also searched the archives of the Ministry of Foreign Affairs, in particular the diplomatic and consular archives. The Ministries of Justice and Foreign Affairs were the responsible departments with respect to intercountry adoption. To map the role of private parties, reconstruct and follow the paper trail of adoption procedures, we accessed the archives of private adoption agencies and intermediaries. In total, we consulted more than 200 larger files, ranging from a handful of documents to hundreds of volumes.

6 R. Hoksbergen, Kinderen die niet konden blijven: zestig jaar adoptie in beeld (Soesterberg: Aspekt, 2011), 5-14.

7 L. Briggs and D. Marre, "Introduction: The Circulation of Children." In International Adoption: Global Inequalities and the Circulation of Children, eds. D. Marre and L. Briggs (New York: New York University Press, 2009), 1-28; E. Loibl, The Transnational Illegal Adoption Market: A Criminological Study of the German and Dutch Intercountry Adoption Systems (The Hague: Eleven International Publishing, 2019), 22, 275-277. 
These files predominantly contained letters, policy notes, protocols, reports, memoranda and codified diplomatic messages. ${ }^{8}$

Our archival research confronted us with two challenges. The first pertained to privacy regulations, in particular to the fact that many archives are not publicly accessible and are subject to confidentiality rules. Because our research for the CIIA was commissioned by the government, we were allowed access, but how could we then publish verifiable data and reference research findings? What were we allowed to publish and what not? And how could we treat personal data with confidentiality and still substantiate our evidence? Unlike with public, scholarly research projects, our governmentally-sanctioned project was granted unrestricted access to all relevant archives, non-public ones included. That means that other researchers cannot replicate some of our findings. For that reason, we negotiated hard to publish verifiable findings and provide references to archives, but with all personal data very strictly anonymized or pseudonymized.

A second challenge for our archival research involved explaining the nature of historical research to the policymakers and judicial officials assisting the CIIA. During the investigation it regularly proved complicated to convince them of what historical research, and in particular archival research, can and cannot do. Relevant archival findings sometimes led to misunderstandings. As historians, we had to navigate between the view that archival findings have to pass a very strict, almost judicial 'burden of proof' test and the notion that 'historical records are just someone's written opinion' The first view is dangerous, because it may result in confirmation bias and tunnel vision (only aiming to find hard evidence); the other completely undermines any form of objectified findings on past positions, thus leading to exaggerated relativism.

We mainly confronted these challenges by finding as much additional research material as possible, corroborating our archival findings with findings from other archives, and contextualizing these findings with media coverage $(1,000+$ articles) and parliamentary documents (e.g. 130 parliamentary questions and dozens of debate records). Moreover, we also adopted the method of oral history. The CIIA conducted almost 200 qualitative interviews with stakeholders, such as representatives of adoption organizations, governmental departments, adoptee associations etc. We further contextualized this data by comparing it and embedding it in secondary literature and our archival findings. By using this historical mixed-methods approach, we were able to identify and trace public information on intercountry adoption abuses known in

8 For a list of all consulted archives, see Report CIIA, 156-158. 
politics and wider society at the time, and compare the information with private and confidential public records on possible abuses, and with accounts by stakeholders in the system. Thus, our archival material was meticulously and adequately verified and triangulated.

Researching past data to establish guilt or abuses, is by no means a new or original endeavor. In fact historians have been doing so since the inception of their discipline as a profession, with the contribution of historians to Vergangenheitsbewältigung and debates on Wiedergutmachung after World War II as the high point. ${ }^{9}$ In our day and age, historians also participate in debates on colonial pasts, slavery, war crimes and genocide. Such historical debates are never intended only to enrich historiography in itself, but also directly contribute to issues of redress, or to enable judicial prosecution or financial compensation. Guilt and abuses in the past can become social and political concerns in and for the present. ${ }^{10}$ Sometimes, groups of activists, disgruntled citizens or minorities try to put historical grievances on the agenda. Governments themselves may commission historians to excavate their 'dirty laundry'—or, on the contrary, help put concerns at rest. A recent and quite controversial example of this is the initiative taken by French president Emmanuel Macron to commission historical research into the abuses and atrocities committed by France in Algeria, during the civil war of 1954-1962. ${ }^{11}$

In the Netherlands, it was the Minister of Justice, urged by parliament and supported by claims issued by adoptees, who commissioned an investigation into abuses within the system of intercountry adoption. This was not unique to the Netherlands. In Belgium, Ireland and Switzerland similar investigations are also under way. ${ }^{12}$ All these research committees are confronted with how to

For a historiographical overview on Wiedergutmachung, see J. von dem Knesebeck, The Roma Struggle for Compensation in Post-War Germany (Hatfield: University of Hertfordshire Press, 2011), 11-14.

10 See, for instance, the surge in recently published monographs and edited volumes on the role of the Dutch municipalities of Amsterdam and Rotterdam in slavery practices. In these publications the authors often dwell on to what extent the remains of the past reverberate in the present. See G. Oostindie, ed., Het koloniale verleden van Rotterdam (Amsterdam: Boom, 2020); P. Brandon, G. Jones, N. Jouwes and M. van Rossum, eds., De slavernij in Oost en West: Het Amsterdams onderzoek (Amsterdam: Het Spectrum, 2020). The report was written by French historian Benjamin Stora. It dealt with France's colonial relations with Algeria but explicitly did not recommend that the French government apologize for the events of the past, advising instead greater transparency with regard to past abuses. This led the government to establish a "memories and truth" commission, headed by Stora. See C. Méheut, "Report Aims at 'Reconciling' France and Algeria, Its Former Colony." New York Times, January 20, 2021. 
'judge' the past from today's perspective. For us, the solution was to reconstruct the facts, and trace the genealogy of the discussion on intercountry adoption in the Netherlands, based on the occurrences and references to abuses in the past, by contemporaries and in media and parliamentary debates at the time, and measured by laws and regulations of the time itself. This was a novel take on the system of intercountry adoption. Before we present our findings, we will first discuss the state of the art in the academic literature on the topic of intercountry adoption, in order to explicate our position and its added value to this field of research.

\section{State of the Art in Academic Literature}

Intercountry adoption is a truly multidisciplinary object of research. It bears on judicial aspects, on social and political scientific dimensions (sociology, political science, anthropology, pedagogy, psychology), and on medical and psychiatric science. Most researchers have a background in American academia, which in itself colors their perspective. What is more, many key researchers are adoptive parents themselves, a positionality that inevitably bears on the analysis. Methodologically speaking, most social scientists base their research on a limited number of adoptees. Survey studies have only been carried out by a few psychologists or pedagogues. ${ }^{13}$ Research covering a long-term period and development of the whole system of adoption as such, has rarely been initiated before.

Since the 1970s, academic debate on intercountry adoption has pivoted around two central questions: first of all, what can possibly be said, on the basis of evidence, about the consequences of adoption for children? And second, what does it mean that the system of adoption rests on the existence of systemic inequalities between the global North and the global South?

Both debates have over the last decades produced research findings that did signal the occurrence of abuses. Yet, these critical voices remained rare or were

brengen na onthullingen over ontvoering en wanpraktijken." Nieuwsblad, October 5, 2020. For Ireland: Department of Children, Equality, Disability, Integration and Youth, Ireland, Final Report of the Commission of Investigation into Mother and Baby Homes (Dublin, January 2021); "Up to 4,000 Irish children sent abroad for adoption over 30 years." Irish Times, February 1, 2021; for Switzerland: S. Bitter, A. Bangerter and N. Ramsauer, Adoptionen von Kindern aus Sri Lanka in der Schweiz 1973-1997 (Zürich, 2020).

13 E.g. M. van IJzendoorn et al., "Institutionalisation and deinstitutionalisation of children 1: a systematic and integrative review of evidence regarding effects on development." Lancet Psychology 7 (8) (2020), 703-720. 
ignored. ${ }^{14}$ Since the 199os, criticism increasingly gained traction. In essence, the fields of debate can be divided into two academic discourses. The legal field has addressed shortcomings in the way intercountry adoption is organized globally in terms of legal arrangements and prevailing laws. ${ }^{15}$ Researchers from the medical, psychological and pedagogical disciplines have tried to assess and map consequences of adoption for the parties involved in the process: the adoptees themselves, birth parents and adoptive parents. The focus of this research is on problems diagnosed with adoptees, such as attachment, physical and mental development and identity-related disorders and afflictions. ${ }^{16}$

Within these academic debates and disciplines, supporters and opponents of intercountry adoption can clash severely. Tensions have arisen around the interpretation of the principle of 'the rights of the child'. Do we need to compound the child's right to care, love and protection within a loving family? Or do we need to focus on the more socially and culturally informed right to grow up within one's own country and culture, to retain one's identity and not be removed from one's community and culture?

Furthermore, a growing stream of academic opponents to intercountry adoption holds that the development of intercountry adoption is the product of Western-led forces of 'commodification' and 'marketization.' ${ }^{17}$ Several scholars

14 For instance, M. de Langen, inaugural lecture (University of Amsterdam, 1976). Cited in: Verstoorde relaties, adoptie en hulpverlening, eds. R. Hoksbergen and W. Wolters (Baarn: Амво, 1989), 52-64.

15 See for the most relevant publications: J. Gibbons and K. Rotabi, eds., Intercountry adoption: Policies, Practices and Outcomes (London: Routledge, 2016); E. Bartholet, "International Adoption: Thoughts on the Human Rights Issue." Buffalo Human Rights Law Review 13 (2007), 151-200; K. Bergquist, "Operation Babylift or Babyabduction: Implications of the Hague Convention on the humanitarian evacuation and 'rescue' of children." International Social Work $5^{2}$ (5) (2009), 621-633; P. Fronek and D. Cuthbert, "History Repeating: DisasterRelated Intercountry Adoption and the Psychosocial Care of Children." Social Policy \& Society 11 (3) (2012), 429-442; P. Selman, "The Global Decline of Intercountry Adoption: What Lies Ahead?" Social Policy and Society 11 (3) (2012), 381-397.

16 See, for instance, L. van den Dries, F. Juffer, M. van IJzendoorn and M. BakermansKranenburg, "Fostering Security? A Meta-Analysis of Attachment in Adopted Children." Children and Youth Services Review 31 (3) (2009), 410-421; M. O'Leary Wiley and A. Baden, "Birth Parents in Adoption: Research, Practice, and Counseling Psychology." The Counseling Psychologist 33 (1) (2005), 13-50; B. Yngvesson, “Going 'Home': Adoption, Loss of Bearings, and the Mythology of Roots." Social Text 21 (1) (2003), 7-27; M. Novy, "Memoirs and the Future of Adoption." Adoption and Culture 9 (2), 308-324; P. Fronek and K. Rotabi, "The impact of the COVID-19 pandemic on intercountry adoption and international commercial surrogacy." International Social Work 63 (5) (2020), 665-67o.

17 M. Goodwin, Baby Markets: Money and the New Politics of Creating Families (Cambridge: Cambridge University Press, 2010). 
assert that intercountry adoption has morphed into something not dissimilar to an 'adoption market', with non-Western, adoptive children as a commodity and Western adoptive parents with their overflowing pockets behavingwittingly or unwittingly — as interested 'buyers' and customers. This adoption market has furthermore emerged against the background of global, structural inequalities, such as poverty, war, and unequal access to justice. ${ }^{18}$ These structural flaws in the system cannot but lead to abuses, and are therefore nearly or totally irresolvable by new laws or regulations. Some international researchers of standing, such as the American law professor David Smolin - an adoptive parent himself-have therefore begun to advocate suspending intercountry adoption in the short term, and perhaps, ultimately, terminating it altogether. ${ }^{19}$

Supporters and proponents of adoption often reject negative frames and findings, and underscore the opportunities for a better, healthier, happier life for children that intercountry adoption provides. When these supporters of the system do acknowledge abuses, they invariably come up with solutions in the context of new, more focused or improved international laws and regulative frameworks, preferably anchored in international treaties. ${ }^{20}$ They assert that children in developing countries are far worse off in orphanages or children's homes than in the care of Western adoptive parents. Intercountry adoption is therefore something, they argue, that is in 'the best interests of the child. ${ }^{21}$

Within these multidisciplinary debates, the rifts between opponents and supporters of the system stand out and are almost unbridgeable, rendering the field very normatively informed and contested. What stands out furthermore is that most studies and arguments on intercountry adoption are highly presentist, and do not, or only to a very limited degree, present an overview of the development of the system over time. Hence, the long-term perspective is conspicuously missing, and researchers are only very recently raising flags about this. Social scientist René Hoksbergen has addressed some trends in the history of intercountry adoption in the Netherlands. ${ }^{22}$ Criminologist Elvira Loibl made

18 Ibid.

19 D. Smolin, "The Case for Moratoria on Intercountry Adoption." Southern California Interdisciplinary Law Journal 30 (2) (2021), 1-10.

20 J. Palacios et al., "Adoption in the service of child protection: An international interdisciplinary perspective." Psychology, Public Policy, and Law 25 (2) (2019), 57-72.

21 As argued by, among others, the pedagogues Van IJzendoorn et al. Their meta-analysis of more than three hundred studies in over sixty countries over the past five decades demonstrates the negative effects of growing up in orphanages, including retarded physical and socio-emotional growth. See Van IJzendoorn et al., "Institutionalisation and deinstitutionalisation of children $1 . "$

Hoksbergen, Kinderen die niet konden blijven. 
a case in her dissertation for introducing a broader historical perspective into the field, which she herself did in her study of intercountry adoption practice in the Netherlands and Germany. ${ }^{23}$ Recently, historian Marlou Schrover also utilized a longer-term historical and comparative perspective in her article on Dutch adoption debates. ${ }^{24}$ Yet, such historical studies remain descriptive, and merely support the overall normative argument that these researchers are aiming to make. Nor do they rely on more comprehensive archival evidence.

The only academics who made the effort to engage with a historical perspective in a substantial way —including the use of some archival data — are Gonda Van Steen and Chiara Candaele. It is therefore important to briefly present their work and findings. Van Steen conducted research into the practice of adoption and its politicization in Greece, in particular after the Greek Civil War of 19461949. She showed how more than 3,ooo Greek children were offered to adoptive parents in the West, in particular in the United States. She concludes that this transfer of children should be considered a 'payment in kind' for the massive economic aid (Marshall Plan, for instance) that the Americans were pouring into Greece within the anti-Communist context of the early Cold War. ${ }^{25}$

Candaele investigated the role of Belgian Catholic agencies in the system of intercountry adoption from postcolonial Africa, in particular Rwanda between 1970 and 1994. She brings into focus how such adoptions in Belgium are rooted in colonial practices dating from before 1950. She identified a string of abuses, such as insufficient provision of information and pressure on birth parents to give away their children. All of these abuses were a result of the wish to expedite the stream of adoptions to Belgium. ${ }^{26}$

In sum, academic research on intercountry adoption in the social sciencesin particular pedagogic, legal and socio-psychologic research-is still very much centered on the contingent question of 'what is in the best interest of the child', thereby dividing the field into two opposing 'camps' of supporters and opponents. A deeper, more thorough historical analysis of the genealogy of the field, of the context of intercountry adoption within the divide between the global North and the global South, has been lacking for a long time. Only recently has the systemic nature of this divide and the longer genealogies of

\footnotetext{
23 Loibl, The Transnational Illegal Adoption Market.

24 M. Schrover, "Parenting, Citizenship and Belonging in Dutch Adoption Debates 19oo1995." Identities 28 (1) (2021), 93-110.

25 G. Van Steen, Adoption, Memory, and Cold War Greece: Kid pro quo? (Ann Arbor: University of Michigan Press, 2019).

26 C. Candaele, "Mother Metropole: Adoptions of Rwandan minors in postcolonial Belgium." BMGN special issue "Child Separation" 134 (3-4) (2020), 209-233.
} 
(abuses in) intercountry adoption policy and practice been addressed. ${ }^{27}$ The CIIA report, and this article, aim to contribute to that scholarship and to fill the gap relating to the Dutch intercountry adoption system. Our article is therefore not a contribution to the debate on the consequences of adoption, nor on the nature or necessity of international legal provisions and regulations, butas we have explained above - an applied historical analysis of concrete abuses within the international adoption system and practice through time.

\section{$4 \quad$ Setting the Scope and Stage of the Research}

The scope of the CIIA research ranges from the 1950s until the present. In the 1950s, Greece was among the first sending countries, together with South Korea. ${ }^{28}$ The majority of Greek adoptees went to the United States, but nearly 600 were adopted by Dutch adoption parents up until 1980, when Greece halted the adoption practice. Van Steen states that the supervision by Dutch organizations and intermediaries was better implemented than in the US, where serious abuses and malpractices were documented. Yet, the cira found it could not be ruled out that abuses such as forced consent also occurred in adoptions from Greece to the Netherlands. ${ }^{29}$ In 1956 the Netherlands passed the Adoption Act, which focused on domestic adoption within the Netherlands itself. To improve the legal framework for intercountry adoption, the Netherlands signed the 1993 Hague Adoption Convention in 1998. Abuses did not, however, cease to occur after 1998, and continue until the present day. We therefore extended the scope of our investigation to 2020 to include discussion of today's abuses.

Geographically, our research generally covers all countries that participated in intercountry adoption with the Netherlands, 80 in total. To substantiate and further excavate evidence on abuses, we focused our inquiries on five countries in particular: Bangladesh, Colombia, Brazil, Indonesia and Sri Lanka. ${ }^{30}$

27 See for instance: A. Oh, To Save the Children of Korea: The Cold War Origins of International Adoption (Redwood City: Stanford University Press, 2015); K. McKee, Disrupting Kinship: Transnational Politics of Korean Adoption in the United States (University of Illinois Press, 2019); K. Cheney and S. Ucembe, "The Orphan Industrial Complex: The Charitable Commodification of Children and Its Consequences for Child Protection." In Disadvantaged Childhoods and Humanitarian Intervention: Processes of Affective Commodifcation and Objectifcation, eds. K. Cheney and A. Sinervo (Cham: Palgrave Macmillan, 2019), 3761.

28 See for the respective sections on Greece and South Korea: Report CIIA, Annex G, 102-104.

29 Van Steen, Adoption, Memory, and Cold War Greece, 273.

30 Besides the five main countries studied in-depth, the CIIA investigated eighteen additional countries. See Report CIIA, 119-121. 
The Minister of Justice identified these countries as objects of our investigation, since they provide ample data and evidence to gauge and understand the mechanisms of the intercountry adoption system and its abuses. This group contains countries that have provided a relatively large number of adoptees $(1,500+$ per country) to the Netherlands, and are among the top 11 countries of origin for adoptive children in the Netherlands. Moreover, the countries selected were all engaged in intercountry adoption over a period of ten years or more, enabling us to carry out our historical research and analysis in a longitudinal perspective. These countries also represent more than a third $(14,500)$ of the total of 40,000 foreign adoptees in the Netherlands. In addition to studying these five countries, we carried out more general research into 18 other countries, which will be described further below.

The five selected countries differ considerably historically, culturally, socioeconomically and politically. Yet, all five were the focus of Dutch intercountry adoption efforts, and subjected to the same official governmental practices and attitudes. Another reason for their selection is that reports on abuses surfacing in the Dutch media since the 1970s have predominantly centered on these five countries. These media reports were substantiated by our archival and oral history research: all imaginable forms of abuse, from forged documents to baby farms', occurred within intercountry adoption from these countries.

\section{5}

\section{Research Findings: Investigating Abuses through Time}

For reasons of brevity, this section focuses on two countries of origin that are considered illustrative for the wider practice of intercountry adoption, Brazil and Sri Lanka. ${ }^{31}$ For both countries the adoption numbers and the historical and legal context are highlighted, after which the prevailing state of affairs of adoption abuses is reconstructed. We then describe the degree to which the Dutch government was aware of or involved in these abuses, how it responded and what conclusions can be drawn from this.

\subsection{Brazil}

Between 1973 and 2008 over 1,80o Brazilian children were adopted by Dutch families. Adoption from Brazil to the Netherlands stopped completely after 2008. From the 1970s children were given up due to a combination of fac-

31 For detailed studies of the three other main countries (Bangladesh, Colombia and Indonesia) researched in the CIIA investigation, see Report CIIA, 39-90. 
tors: the influence of Catholicism, poverty, the young age of mothers and the low status of children born out of wedlock. Such children were institutionalized not because they were genuine orphans, but because their mothers-the father was usually absent-were not able or willing to look after them. Brazilian mothers felt compelled or were forced to relinquish their children, in many case for intercountry adoption. ${ }^{32}$ Recent studies have shown that many mothers were not aware of the definitive and irreversible nature of adoption. These insights still largely hold true to this day. ${ }^{33}$

Until 1979 there was little legislation regulating adoptions. Intercountry adoption was managed outside the purview of public legal institutions and could be arranged by local, private lawyers. Brazilian intermediaries, especially lawyers and notaries, received on average USD 10,000 per child for their services. The deficient legal and regulatory framework allowed adoptions to the Netherlands to be conducted with no formal procedures till the end of the 1980s. The data of biological parents were rarely recorded and documentation left much to be desired. ${ }^{34}$ This state of affairs slowly changed in later years. From 1990 adoptions could only be effectuated through a public court. The mother had to relinquish her child explicitly for this court, and intermediation by private parties was prohibited by law. ${ }^{35}$

32 See C. Fonseca, "Orphanages, Foundlings, and Foster Mothers: The System of Child Circulation in a Brazilian Squatter Settlement." Anthropological Quarterly 59 (1) (1986) 15-27; Fonseca, "Inequality near and far: Adoption as seen from the Brazilian favelas." Law \& Society Review 36 (2) (2002), 397-432; Fonseca, "An Unexpected Reversal: Charting the Course of International Adoption in Brazil." Adoption \& Fostering 26 (3) (2002), 28-39; A. Cardarello, '"Legal Child Trafficking': Adoption and Poverty in Brazil." Journal of Latin American and Caribbean Anthropology 14 (1) (2009) 140-161; Cardarello, "The Right to Have a Family: 'Legal Trafficking of Children." Anthropology \& Medicine 19 (2) (2012), 225240.

33 The birth mothers were not aware that the (legal) bonds between them and their children would be severed, see A. Cardarello, "The Movement of the Mothers of the Courthouse Square: 'Legal Child Trafficking,' Adoption and Poverty in Brazil." Journal of Latin American 1 (2009) 140-161, 144-145; C. Annuate, "Psychological problems of late adoption as observed in Brazil through a cultural-historical approach." Psychology in Russia 6 (4) (2013), 176-184, 176-177; A. Cardoso Siqueira et al., "Ensuring the Rights of Birthmothers to Place Their Children for Adoption." In Vulnerable Children and Youth in Brazil: Innovative Approaches from the Psychology of Social Development, eds. D. Dell'Aglio and S. Koller (Cham: Springer, 2017), 169-188, 171-174.

34 Wereldkinderen brochure on Brazilian adoptions, in Minjus archives, access Ов Р7, file 10; Carvalho da Silva, "The Legal Procedures for Adopting Children in Brazil", 128-129; Fonseca, "An Unexpected Reversal", 33-34.

35 Fonseca, "An Unexpected Reversal", 32. For the role of jurists in intercountry adoption practices, see D. Abreu, "Baby-Bearing Storks: An Analysis of Brazilian Intermediaries in 
As early as the 1970s, Dutch and international media were drawing attention to illegal practices, including child trafficking, surrounding adoptions from Brazil. Various involved parties declared that Brazilian adoptions had been characterized by extreme and systematic malpractices for decades. ${ }^{36}$ Archival research confirms this picture, as demonstrated in the Brazilian cases presented below.

\subsubsection{Illegally Operating Couple, 1971-1972}

The first well-documented case concerned a Dutch couple who adopted a Brazilian child in 1971. They planned to register the child as their own with the Brazilian authorities, so that they were documented as the biological parents on the child's birth certificate. Under Dutch law, such conscious concealment of identity is - and was then - a punishable offense. Archival research showed that a Brazilian official with Dutch roots, together with a Dutch diplomat, were not only aware of this case, but had actively provided assistance. ${ }^{37}$

One year later, in 1972, the Dutch authorities were informed of the illegal adoption. The Public Prosecutor's Office initiated an investigation into the case and the role of the aforementioned officials. ${ }^{38}$ Subsequently the Public Prosecutor informed the Ministry of Justice, highlighting the interest of the child. The Ministry of Foreign Affairs and the diplomatic missions then also became involved. Despite suspicions of illegal acts and the "strange attitude" of the Dutch official in question, the government agencies decided not to initiate a prosecution, claiming that both the couple and the Dutch official had acted in good faith and the illegal adoption was not punishable in Brazil. The Dutch embassy considered it unnecessary to inform its Brazilian counterpart about the case. ${ }^{39}$ This case did not attract political or media attention at the time, but when later Brazilian adoption abuses came to the fore,

the Adoption Process." In International Adoption: Global Inequalities and the Circulation of Children, 148-150.

36 Based on interviews held by cıı. See also “Babysmokkel ontdekt in Brazilië." Telegraaf, April 12, 1973; "Van Braziliaanse adoptiekinderen meer dan helft illegaal." $N R c$ Handelsblad, February 6, 1984; "Brazilië: handel in bevroren kinderen?", Het Vrije Volk, September 27 1990.

37 Personal letters found in Ministry of Justice archives, 8 June 1971 and 21 June 1971; Letter from Dutch consul in Brazil, 8 July 1971, MinJus archives, access 500o.o17, inv.no. 3984.

38 Report by municipal police in Emmen, 19 September 1972, MinJus archives, access 5 ooo.o17, inv.no. 3984 .

39 Ibid.; see also correspondence between the Ministries of Justice and Foreign Affairs and the Attorney General in MinJus archives, access 500o.017, inv.no. 3984; Letter to Attorney General Leeuwarden, 11 July 1973, MinJus archives, access 500o.o17, inv.no. 3984. 
the media referred back to it. Especially after 1978, suspicions of similar illegal adoptions from Brazil increasingly emerged. The Dutch authorities argued they could not do anything to combat such practices. This changed, however, in the 198 os. $^{40}$

\subsubsection{Large-Scale Police Investigation, 1981-1984}

From December 1981 till March 1984 a nationwide police investigation was carried out in the Netherlands. At the instigation of the Public Prosecutor's Office a police team researched to what degree children from South America, especially Brazil and Colombia, had been adopted illegally by Dutch couples. The Public Prosecutor's Office suspected that illegal practices, including fabricating false identities, profiteering and child trafficking, had occurred on a large scale. ${ }^{41}$ Meanwhile, the Ministry of Justice prejudged the outcomes of the investigation. Despite being alarmed about the widespread nature of the illegal practices, it nonetheless remained unprepared to remove the children concerned from their homes. ${ }^{42}$

The police investigation was completed in September 1983. The final conclusion was that dozens of Dutch couples had illegally registered a Brazilian child as their own biological offspring. As a result of the investigation, 42 couples admitted their illegal actions. In March 1984 the Public Prosecutor's Office gave its final verdict and decided to dismiss all charges. None of those involved in the cases were criminally prosecuted, a decision which was applauded by the responsible authorities in the Netherlands. ${ }^{43}$ After completion of this largescale police investigation no significant measures were taken by the Dutch government to prevent similar illegal adoptions in the future. The only concrete measure consisted of making supervisory parties such as airports, customs authorities and embassies aware of the need to check the documents of incoming adoption children more scrupulously. ${ }^{44}$

$40 \quad$ "Jarenlang in dure verwachting." $N R C$ Handelsblad, July 1, 1978; letter from the Legal Affairs Department at Ministry of Foreign Affairs to the Dutch ambassador in Brazil, 2 June 1978, MinJus archives, access 5000.017, inv.no. 3984.

41 Letter from District Attorney to the Attorney General in Amsterdam, 7 December 1981, MinJus, Public Prosecutions Service archives, access 2.09.132, inv.no. 349 .

42 Minutes of meeting of Attorneys General, 9 December 1981, MinJus, Public Prosecutions Service archives, access 2.09.132, inv.no. 350.

43 Minutes of meeting of Attorneys General, 7 March 1984, MinJus, Public Prosecutions Service Archives, access 2.09.132, inv.no. 396; Note Directory Child Protection to the Minister and State Secretary for Justice, 19 March 1984.

44 Agenda of meeting of Attorneys General, point 11: "Report on illegal adoptions" 15 February 1984, MinJus, Public Prosecutions Service archives, access 2.09.132, inv.no. 396. 


\subsubsection{Rumors of Child Trafficking, 1985-1994}

In the late 1980 os and early 199os suspicions of Brazilian adoption abuses continued to surface in national and international media. There were persistent rumors that children were being abducted for adoption, only to end up in prostitution or even involved in the trafficking of organs. ${ }^{45}$ In 1992 questions were asked in parliament about Dutch involvement in Brazilian crime syndicates that were allegedly conducting tens of thousands of child abductions. The Minister of Justice replied there were no indications of such practices but that intercountry adoption should be more closely controlled. ${ }^{46}$

In 1994 continuing rumors of trade in children led the court in the Brazilian state of Pernambuco to declare a temporary ban on intercountry adoption. The Dutch Ministry of Justice responded by instigating an investigation, which concluded that all children from Pernambuco in the Netherlands were in good health. This finding was shared with the Brazilian authorities, partly with the aim of resuming the adoptions. Archival research showed that this in fact happened a few years later. ${ }^{47}$

\subsubsection{Aftermath of Brazilian Adoptions, 199os-Present}

Since the turn of the century, Brazil has increasingly been restricting intercountry adoption. The reasons for this are improved local conditions, declining poverty, better legal and procedural frameworks, and changing public opinion as a consequence of a continuing flow of reports on adoption abuses. ${ }^{48} \mathrm{How}-$ ever, abuses have not stopped, even since the ratification of the Hague Adoption Convention (HAC) by the Netherlands (1998) and Brazil (1999). Unlike Sri Lanka, Brazilian adoptions continued till around 2008. Especially since 2006 several abuses-such as forgery of adoption papers and the removal of children by local authorities without clear reasons-have been made public. ${ }^{49}$

45 "Kind Koopwaar: Politie wil actie tegen Braziliaanse misdadigers." Algemeen Dagblad, September 10, 1992; "Levendige handel in kinderen Brazilië: Ontvoeringen voor adoptie zaaien angst onder bevolking." Trouw, September 23, 1988; "Twijfels over alarm kinderen orgaanhandel in Italië." Nieuwsblad van het Noorden, September 23, 1994; “'Kind koopwaar'; Brazilië onderzoekt handel in kinderen." Het Parool, March 28, 1991.

46 Parliamentary Question Dijkstal to Minister of Justice on: "on the Dutch involvement with Brazilian criminal organisations that kidnap children”, 11 September 1992.

47 Letters ministry of Justice to consulate-general Brazil in The Hague, 10 November 1994 and 24 February 1998, in MinJus Archives, C-Files, access 500o.o16, inv.no. 6o.

48 K. Cheney, “'Giving Children a Better Life?' Reconsidering Social Reproduction Humanitarianism and Development in Intercountry Adoption." European Journal of Development Research 26 (2014), 247-263, 254.

49 Cardarello, "The Right to have a Family", 237. 
In short, adoption abuses in Brazil were widespread. Forgery of documents, identity fraud, and corruption occurred systematically, as did abduction and trade in children. Especially in the 1970s and 1980s, Dutch couples wittingly adopted Brazilian children illegally, registering dozens as their own biological offspring. This was and remains a punishable offense in the Netherlands. During these adoptions, documents were forged, leading in turn to fraud and corruption. The Dutch government has been increasingly aware of these abuses since the early 1970s. Two government officials - a consul and a civil servantwere implicated in two separate illegal adoptions. Our archival research did not provide any indications whether such involvement happened on a systematic scale in intercountry adoptions from Brazil.

\subsection{SriLanka}

Most adoptees from Sri Lanka came to the Netherlands in the 1980s, amounting to several hundred per year. After 1992 this number fell to about ten per year, and after 2010 at the most two per year. There are currently about 3,500 Sri Lankan adoptees in the Netherlands. ${ }^{50}$ Prominent features of the Sri Lankan context over the last half century were poverty and the disruptive civil war. Corruption was and continues to be pervasive in Sri Lanka. In socio-cultural terms unmarried motherhood was surrounded by strong taboos and stigma. Social exclusion occurred regularly, and also extended to the children at a later age. This web of conditions forced young mothers to relinquish their children, including for adoption. Pressure or even coercion by the family and the wider community was a regular occurrence. ${ }^{51}$

There were no legal arrangements pertaining to intercountry adoption in Sri Lanka until 1979, when it became officially possible. The 1944 Adoption of Children Ordnance (which was revised in 196o and 1964) only provided a legal basis for domestic adoptions. ${ }^{52}$ Nevertheless intercountry adoption occurred from the early 1970s. The outdated, non-compatible legislation and dysfunctional governmental and private agencies, such as the Child Probation Service and local children's homes, left scope for fraud, bribery and corruption by officials, lawyers and other intermediaries. Supervision in Sri Lanka was minimal, and document forgery was widespread. ${ }^{53}$

$50 \quad$ Hoksbergen, Kinderen die niet konden blijven, 141.

51 Based on interviews held during fieldwork in Sri Lanka, August 2019. See also unpublished brochure "Adoption in Sri Lanka", 27 February 1989, 17-18, in MinJus archives, access овр11, file 3 .

52 Adoption of Children Ordnance, 1956, revision 1960; Adoption of Children Ordnance, Law No. 6 of 1977 (Act No. 38 of 1979), chapter 76, part 1, section 3.6, in Ministry of Foreign Affairs archives, inv.no. ooo659/6293.

Based on field work interviews in Sri Lanka, August 2019. See also unpublished brochure 
These abuses continued for many years since the 1970s. The situation began to change slowly after Adoption Ordnance was amended in 1992, tightening up the regulations. ${ }^{54}$ That legal change was facilitated by societal indignation about adoption abuses both in Sri Lanka itself and abroad. The 1992 amendment act prioritized domestic adoption and established a quotum for intercountry adoption. Intercountry adoption would only be possible when all domestic options of child protection were considered impossible by the responsible authorities. The implication of this practice was that Sri Lanka implemented the subsidiarity principle before it was codified in the Hague Adoption Conference in 1993. Only children from registered homes could be adopted, it became punishable to keep pregnant women or children in custody, and payments to Sri Lankan intermediaries were prohibited. These measures were taken explicitly in response to the infamous baby farms that had been discovered and dismantled in the preceding years. ${ }^{55}$ Unlike the earlier legislation, the 1992 Act was monitored more closely. Archival research has, however, shown that, despite legal and procedural frameworks offering sufficient guarantees on paper, serious abuses have continued to occur. Most took place in the 198 os, but abuses also occurred in the 1970 s and up until the early 2000s. Below we examine a number of cases exemplifying abuses in intercountry adoptions from Sri Lanka.

\subsubsection{Baby Farms, 1987-1995}

Suspicions of illegal trade in adoption children had been voiced in Sri Lankan media since 1987. The Dutch embassy in Colombo was regularly informed about these suspicions but, despite at least one Dutch diplomat considering the reports credible, tended to see the media as sensational and exaggerating the situation. ${ }^{56}$

In mid-1987 a Sri Lankan investigation committee published a devastating report. According to the committee only 37 out of 1,670 adoptions from Sri Lanka were legal and had been conducted through the official channels. Following this report the Sri Lankan government decided to impose a temporary

'Adoption in Sri Lanka', 27 February 1989, 17-18, in MinJus archives, access овP-11, file 3 .

54 Adoption of Children Ordnance, Adoption of Children (Amendment) Act, no. 15, 1992 (March, 1992).

55 Baby farms are sites where women are impregnated or held voluntarily, involuntarily or for payment to deliver their children for intercountry adoption or other purposes.

56 Codified message from Dutch embassy in Colombo to Ministry of Foreign Affairs, 26 January 1987; Reply from 29 January 1987, both messages in MinJus archives, DEcos-files a87/701/101179o. 
ban on all, including intercountry, adoptions. The ban was however not adequately upheld, as shown by Dutch adoption figures from that period. ${ }^{57}$ The adoption stop led to vicious comments in the Dutch media, with Dutch intermediaries even accusing each other of "child hunting". ${ }^{5}$ Dutch government agencies were also concerned about the adoption abuses. The Child Protection Agency noted serious problems and stated that supervision was a task not only for foreign authorities, but also for Dutch ones. This view was not shared by the Ministry of Justice. ${ }^{59}$

The Dutch government was informed in detail about the existence of baby farms in Sri Lanka. After delivery the child would be relinquished in a court hearing for intercountry adoption by an 'acting mother' who pretended that it was her own child. The Dutch embassy explained and discussed the existence of baby farms in several memoranda. The embassy stated that the Sri Lankans saw baby farms as "morally reprehensible", but that "the temptation was strong in view of the financial inducements where they shrewdly appealed to the desire of many in the Western world to adopt children". ${ }^{60}$

The network of child traders around the farms consisted of a number of key Sri Lankan individuals, including a lawyer and two former officials of the Child Probation Office. They served as local intermediaries for Dutch, British and other Western adoption agencies. The three intermediaries were involved in a total of over 300 intercountry adoption cases. They were closely monitored by the Sri Lankan, British and Dutch authorities. In 1987, they were the subject of a police investigation; and in 1991 one of their baby farms was closed by the Sri Lankan police. ${ }^{61}$ The lawyer fled to Britain where she obtained a visa without

57 Ministry of Justice, Adoptie: Trends en Analyse. Statistisch overzicht interlandelijke adoptie. 9 vols. (The Hague, 2007-2020). The Sri Lankan ban on adoptions was lifted in September 1988 , a year after it had been established.

$5^{8} \quad$ "Schokkend rapport over babyhandel Sri Lanka." Nederlands Dagblad, April 10, 1987; Codified message 'most immediate' from Dutch embassy in Colombo to Ministry of Foreign Affairs, Legal Affairs Department, 4 June 1987, MinJus archives, Decos files, inv.no. a87/701/101179o. See also "Hoe een olifant en een muis twee tijgers werden: Sri Lanka, nieuwe markt adoptiebureaus?", Het Vrije Volk, April 18, 1987; "Sri Lanka verbiedt adoptie van kinderen door buitenlanders", Volkskrant, June 5, 1987.

59 Letter from Child Protection Agency to Parliamentary Committee on Justice, 31 March 1987, MinJus archives, DEcos-files, inv.no. a87/701/101179o.

6o Memorandum from Dutch embassy in Colombo to Ministry of Foreign Affairs, 17 January 1990; Codified message from embassy in Colombo to Ministry of Foreign Affairs, 26 September 1990, both in Foreign Affairs archives, access DAz/Jz/-sz/ARA/oo166, inv.no. 136 .

61 Report on inspection visit by Ministry of Justice to adoption bureau, 12 November 1991, MinJus archives, овр-о8, file 1; Memorandum from Dutch embassy in Colombo to 
any problems. Despite all concrete signs of abuses, the Dutch agencies continued to use the lawyer as their contact person until at least $1995 .{ }^{62}$ Archival research showed that, despite the knowledge and disapproval of these abuses for many years, the Dutch government did not take any action. ${ }^{63}$

\subsubsection{Aftermath of Sri Lankan Adoptions, 199os-Present}

After the new legislation of 1992 and the implementation of the Hague Adoption Convention (as one of the first countries in the world), the number of intercountry adoptions from Sri Lanka declined. Between 1998 and 2021 about 100 adoptees came to the Netherlands. A remarkable fact is that, soon after the destructive tsunami in 2004, Sri Lanka adopted a Special Provisions Act that prohibited the adoption by foreigners of 'orphans' who had allegedly lost their parents in the disaster. The Sri Lankan authorities feared large-scale theft and trade in children in these chaotic conditions. ${ }^{64}$

In the last decade, there has been a lot of attention for past Sri Lankan adoption abuses in the national and international media. ${ }^{65}$ Early 2020 the Swiss government published a research report accounting for its role and involvement in the abuses in Sri Lanka. The Swiss results match those of the Netherlands, both in terms of the main findings and of different details. This is an indication that the adoption system is not a phenomenon confined to the Netherlands

Ministry of Foreign Affairs, Legal Affairs Department, topic: "Adoption/arrest employees of 'baby farm"', 30 August 1991, Foreign Affairs archives, access DAz/Jz/-sz/ARA/oo166, inv.no. 136 .

62 Ibid.; Letter from Directory Youth Protection Ministry of Justice to Ministry of Foreign Affairs, 2 October 1991, Foreign Affairs archives, access DAZ/JZ/-sz/ARA/oo166, inv.no. 136; Letter from Youth Protection Directorate at Ministry of Justice to Public Prosecutions Service, Arnhem, 2 October 1991, NL-HaNA, Immigration and Naturalisation Service archives, inv.no. 3180; Letter Dutch embassy in Colombo to ministry of Foreign Affairs, 6 November 1991, Foreign Affairs archives, access DAz/Jz/-sz/ARA, inv.no. 136.

63 Memorandum Dutch embassy in Colombo to ministry of Foreign Affairs, 26 March 1991, Foreign Affairs Bz Archives, DAz/Jz/-sz/ARA inv.no. 136; Memorandum Dutch embassy in Colombo to Directory Judicial Affairs, 23 July 1991, Foreign Affairs archives, DAZ/JZ/Sz/ARA, inv.no. 137 .

64 For an interesting study on the relation between intercountry adoption and natural disasters with Haiti 2010 as case study, see M. Dambach and C. Baglietto, "Haiti: 'Expediting' Intercountry Adoptions In The Aftermath Of A Natural Disaster: Preventing Future Harm." International Social Service, August, 2010.

65 See, for instance, "Adoption Fraud" episodes from Dutch investigative journalist programme Zembla, episode 1, 17 May 2017, ep. 2, 20 September 2017, ep. 3, 28 March 2018, ep. 4, 27 November 2020. See also '“There were a lot of baby farms': Sri Lanka to act over adoption racket claims." The Guardian, September 20, 2017; "Child trafficking in Sri Lanka Police bust ‘Baby Farm' racket; one arrested.” Daily Mirror, December 23, 2020. 
alone, but may be considered a wider problem that begs further research in other Western countries. ${ }^{66}$

In sum, the archival research has shown that the documented abuses with regard to Sri Lanka were very serious and covered all imaginable variants, from deficient administration to baby farms. These abuses were not only in contravention of the laws and procedures in force at that time, they were also ethically irresponsible. Dutch government agencies became aware of these abuses in detail from the early 198 os onwards. They did not act when confronted with suspicions of trade in children or other abuses, despite Dutch diplomats in Sri Lanka sending out clear signals. Though the government expressed its desire for a firmer approach, it did not act accordingly, looking to the Sri Lankan government for solutions.

\subsection{Abuses Elsewhere after 1998}

To demonstrate that abuses did not occur only in the two countries discussed above or in the period before 1998, when the Netherlands ratified the Hague Adoption Convention, we shall briefly discuss a number of other countries. Many adoptees also came to the Netherlands from these countries, especially from the late 199os onwards, and here too there were clear indications of abuses. The countries we examine are China, Congo and Haiti. ${ }^{67}$

From China, over 6,500 children were adopted to the Netherlands from the late 1990s onwards. Various sources independently and simultaneously recorded structural malpractices. ${ }^{68}$ These related to a broad spectrum of abuses: from forged documents to theft of children. Such accusations led the Dutch Ministry of Justice in 2008 to request the Chinese authorities to instigate an investigation. This did not yield any result and the minister concluded that adoptions from China were "vulnerable". The core of the problem is that China

66 Bitter, Bangerter and Ramsauer, Adoptionen von Kindern aus Sri Lanka in der Schweiz 19731997.

67 Indications of abuses were not limited to these three countries. Serious abuses also occurred in a dozen other countries. See, for instance, Report cIIA chapters 9 and 10, 105122, and Report CIIA, Appendix G, 101-114.

68 Council for the Administration of Criminal Justice and Protection of Juveniles (RSJ), Bezinning op interlandelijke adoptie (The Hague, 2016), 69-80; Letter from State Secretary of Justice to parliament, 4 October 2012; Parliamentary Questions from De Roon to Minister of Justice on: “Stolen Chinese adoption children", 3 July 20o9; Parliamentary Questions from De Pater-Van der Meer to Minister of Justice, 20 August 20og; Langkamp to Minister of Justice on: "Adoptions from China", 3 o November 20o9; Kooiman to State Secretary of Justice on: 'Illegal adoptions from China', 13 May 2011; P. Goodman, "Stealing Babies for Adoption." Washington Post, March 12, 2006. 
does not allow foreign governments to carry our investigations into abuses, despite being obliged to do so as a signatory of the HAC. ${ }^{69}$

From Congo, only relatively few adoptees came to the Netherlands- 140 since 2005. Nevertheless, there were structural indications of abuses, such as malpractices and the theft of children. This led the Congolese government to stop issuing exit visas for adoption children at the end of 2013. ${ }^{70}$ The Dutch government however made a determined effort to get the well-advanced adoption procedures of thirty Congolese adoptees completed. The State Secretary for Justice even travelled to the country with a delegation. This diplomatic pressure was successful: the Congolese authorities agreed to continue the adoptions. Shortly afterwards, the Dutch government itself stopped adoptions from Congo, partly because of continuing indications of abuses in the media. ${ }^{71} \mathrm{In}$ this case-where the interests of the adoption parents were explicitly taken into account - the Dutch government took action. As we saw earlier, this pattern has been seen more frequently in the history of intercountry adoption. ${ }^{72}$

From Haiti, some 1,100 adoptees came to the Netherlands. The abuses in the country were and continue to be very serious. Intermediaries from the Netherlands were involved in the abuses, leading to the temporary cancellation of the license of one Dutch intermediary agency. It did not, however, prompt a structural revision of policies, as is clear from various parliamentary debates and media coverage. ${ }^{73}$ In 2010, in the immediate aftermath of the devastating earthquake, over 2,00o children left the country for adoption, including over 100 to the Netherlands. The Netherlands sent an airplane to bring Haitian adoption

69 "Adoptie uit China vaak illegaal." Brabants Dagblad, March 12, 2008; "Minister wil extra garanties voor adoptie uit China." ANP, March 14, 2008; "Boycot is doodsteek voor adoptie: Minister Hirsch Ballin neemt misstanden in Chinese tehuizen voor lief." Trouw, September 11, 2008.

70 Based on interviews by CIIA; see also US government information on Congolese adoptions, via: https://www.uscis.gov/archive/adoption-information-democratic-republic-of-t he-congo-drc.

71 "Adoptiekinderen mogen Congo eindelijk uit." ANP, November 2, 2015; "Congo: 69 adoptiekinderen mogen vertrekken." NRC Handelsblad, November 3, 2015; "Nederland schort adopties uit Congo op." ANP, September 13, 2016; "Peuters geroofd voor adoptie." Noordhollands Dagblad, May 6, 2017.

72 N. Cantwell, "The Best Interests of the Child in Intercountry Adoption" (Florence, 2014), 43; B. San Román and K. Rotabi, "Rescue, red tape, child abduction, illicit adoptions, and discourse: Intercountry adoption attitudes in Spain." International Social Work 62 (1) (2019), 198-211; Letters from State Secretary for Justice to parliament, 5 January 2015 and 12 April 2016, 13 September 2016, via: https://www.tweedekamer.nl/kamerstukken.

73 Report on inspection by Ministry of Justice to adoption bureau, 19 January 1995, MinJus archives, овр-08, file 1. 
children to the Netherlands more quickly. Within a few days after the earthquake this 'babylift' was carried out by a small number of Dutch diplomats and a dozen volunteers. Some international agencies had warned against such practices, as the chaotic situation in the country could easily lead to doubts about the children's origins. ${ }^{74}$

Two months later, the Dutch government decided to declare a temporary ban on adoption from Haiti as the political and administrative breakdown in the country strongly increased the risk of illegal adoption practices. It remains an open question why this risk was considered then, but not immediately after the earthquake. The Dutch authorities had already been aware of the bribery and corruption of the Haitian government for many years. Later it would emerge that many of the children adopted after the earthquake had not lost their parents at all, many of whom were still assiduously searching for their children. ${ }^{75}$

The most important parallels in the above cases are that abuses did occur in almost all countries around the world and did not disappear after 1998. They were discussed extensively in the media, political circles and in wider society. The Dutch government usually responded by referring to the authorities abroad. If the government did act, it was in cases where the interests of the adoption parents were at stake. The HAC, which forms the legal basis for the international adoption system, has provided insufficient legal guarantees. The implementation of the HAC has not put a stop to the abuses, and the adoption system remains vulnerable. Below we explain why this is the case.

\section{Discussion}

In this paper we have discussed how the notion of 'abuses' in intercountry adoption can be historicized, the challenges and pitfalls of identifying past abuses, and what added value historians can offer in contributing to large-scale governmental inquiries and ultimately to critical policy-analyses and improved policymaking.

First of all, we historicized intercountry adoption abuses by analyzing the train of abuses as part of a system. The documented structural and systematic abuses are caused by a complex of factors in both the countries of origin and

74 Parliamentary Questions De Pater-van der Meer to Minister of Justice on: "abuses with regard to adoptions in Haiti", 15 May 2008; "Kinderen verdwenen uit ziekenhuizen Haïti." ANP, January 22, 2010.

Loibl, The Transnational Illegal Adoption Market, 112-113, 328. 
the Netherlands. These factors continue to be relevant until this day. One factor is the domestic context: In countries of origin children became displaced and sometimes orphaned through poverty, wars and disasters. Unmarried motherhood was rarely accepted socially and culturally. Some adoption parents wanted to help deprived children out of idealism, while others wanted to fulfill a deep desire to have children. The societal discourse in the West, including the Netherlands, was that intercountry adoption was 'doing good' i.e. 'saving children in need'.

That positive image remained dominant, despite increasing evidence to the contrary. The notion that everybody benefits from intercountry adoption explains why the Dutch government and intermediary organizations did not act to stop abuses. For a long time, the Dutch government also saw intercountry adoption as a private matter. It did not want get involved in or frustrate the adoption process, or damage diplomatic relations with other countries.

The adoption system had-and continues to have-few checks and balances. Supervision and monitoring are minimal. The system has insufficient tools and instruments to counter abuses. As a consequence, the interests and rights of the child — for example with regard to knowing its own identity —are insufficiently guaranteed and are subservient to those of the adoption parents.

This amalgam of factors has led to the creation of an intercountry adoption system as an 'adoption market' where market mechanisms have free play. The 'demand' for adoption children grossly exceeded the 'supply' and the amounts paid (varying from hundreds to thousands of dollars for the intermediation of a child) presented perverse financial stimuli. These payments, amounting to more than the annual income of an average Bengali, Sri Lankan or Haitian, led to corruption and other abuses.

Second, we tried to avoid challenges and pitfalls by unearthing and reconstructing past abuses on the bases of historical evidence, archival research, and semantic notions and discourse at the time the abuses occurred. Here, our research on behalf of the CIIA revealed that abuses related to intercountry adoption were of a structural and endemic nature. Abuses took place throughout the entire period of the research project-from the 196os up until the present day. They were not limited to a specific moment in history or a specific place or situation, but were encountered in more than eighty countries of origin. Crucial factors that caused these abuses to become endemic were the excess demand for adoption children, combined with the aforementioned financially-driven asymmetrical global 'adoption market'.

From the late 196os, the Dutch government was aware of abuses relating to intercountry adoption, an awareness that went hand in hand with the rise 
in the numbers of adoption transactions. The government failed to intervene in situations where it knew of specific and concrete abusive situations. Additional checks, balances and regulations were long overdue, while oversight and accountability were often absent. Hence, our main conclusion is that abuses could and did persist unabated.

With these analyses we add to the existing field of research, that has remained locked for too long in a normative and vehement opposition. We have done so by uncovering long-term, factual, evidence-based patterns. We used applied history and social science methods to contribute to the field of adoption studies both conceptually and empirically. Thus, by carrying out an inquiry based on a deep dive in the archives, conducting a large number of oral history and key-informants' interviews, and corroborating media reports, parliamentary questions and data from both governmental agencies and private intermediary adoption bureaus, we demonstrated that it is possible to historicize abuses in the policy and practice of intercountry adoption. Moreover, we analyzed these abuses over a long period and came to the conclusion that abuses in both the legal and ethical sense were systemic and depended not only on the wrongdoings of individuals, but also and foremost on the structural inequalities and systemic lack of oversight and accountability induced by the system itself. Since intercountry adoption depends not only on international treaties for regulation, but hinges on the principle of intercountry trust and non-intervention in international relations, it seems highly unlikely that one single country can assure that the country of origin is adequately positioned to prevent abuses in the practice of intercountry adoption.

Even when reports on abuses appeared in the media - and they frequently did throughout the researched period-, we were able to establish that the Dutch government and embassies hardly followed up on these reports. Not only were investigations rarely instigated, but even when they were, they were invariably blocked, aborted or put to rest on the basis of quite superficial considerations, often by ignoring available evidence.

In the third place, rather than participating in current legal, pedagogical or social-psychological discussions on the consequences of adoption for children, we aimed with this investigation to contribute to the contextualization and historicization of the phenomenon of intercountry adoption as a system. We believe that the added value of historians on such policy-charged dossiers lies exactly here: without further polarizing or politicizing the question of the desirability of adoption, we thus identified vectors and mechanisms within the system, that were operational from the beginning and that were not fundamentally altered over time - not even by the conclusion of international treaties. Instead of focusing on individual cases or the alleged benefits to individual adoptees- 
as mostly happens during debates in parliament or in the media-we collected evidence and traced patterns throughout countries, decades and across different adoption routes.

One of our most fundamental findings was that intercountry adoption, which was originally formalized and inaugurated to protect children and save children in need, has gradually changed into its opposite. Historically speaking, the principle of 'child protection' is highly contingent. It can, and had, different meanings, depending on the power configuration in the field of intercountry adoption. That field was structured by inequalities: between countries (rich and poor), between parties with hardly a say (birth mothers) and parties with financial wealth and influence (adoptive parents). The field was moreover structured by mechanisms resting on the fact that foreign adoptees came to be perceived as a 'commodity', involving commercial parties, private agencies (with interests of their own) — and without adequately staffed governmental sectors that applied oversight and held these parties accountable. Only when the adoptees came of an age that they wanted to know more about their backgrounds, and were able to speak out and demand accountability (in the Netherlands, since the 2010s), did the pressure rise on the Ministry of Justice to instigate an investigation, leading to the CIIA report and the temporary moratorium on intercountry adoption announced in 2021.

\section{7}

Conclusions

Historians are trained to avoid present-day biases. By relying on sources and reports on abuses from the period itself, we have followed this principle of historicization. And by investigating the occurrence of incidents over time, across countries, before and after the implementation of the HAC in 1998 and by corroborating all sources, we have been able to demonstrate that intercountry abuses were systemic rather than anecdotal. What we have done is provide deeper insights into the structural inequalities and commodification of intercountry adoption within the system of international relations, with its NorthSouth divide, and its marketization of rich, Western parents' desire to have 'offspring of their own'. In this way we have tried to provide an analysis that focused on the systemic aspect of the intercountry adoption policies and practices rather than on the benefits and problems associated with intercountry adoption for the individual parties involved, as was a main theme in most scholarly work and public debates on the topic in the past. Our systemic approach tallies with similar, more recent analyses in scholarship as discussed in sections 3 and 4 above. 
On the basis of our findings and analyses, the CIIA made three policy recommendations to the Dutch government. The first recommendation was to acknowledge that the government had failed to adequately tackle adoption abuses. This was deemed necessary in order to repair the damaged relationship with adoptees, parents and others involved. Immediately after the publication of the CIIA report in 2021, the responsible Minister for Legal Protection publicly recognized the government's shortcomings and offered its apologies to all people concerned. The second recommendation was to put a moratorium on intercountry adoption, since it could not be maintained in its current form. Pending the outcome of the decision-making process, the committee recommended the suspension of intercountry adoption. That recommendation was also followed, as was the third, which recommended to set up an independent National Centre of Expertise which combines knowledge about matters of identity, searching and follow-up care. The Centre is still in the process of being established. Hence it can be argued that our research resulted in an immediate policy impact. As per 2022, it is now up to the newly formed government and Parliament to decide whether intercountry adoption will still be allowed in the Netherlands in one way or another in the future, or will be suspended entirely.

\section{Acknowledgments}

The authors are grateful to two anonymous reviewers for their useful suggestions on an earlier draft of this article. They wish to thank all persons involved in the CIIA for their pleasant and stimulating cooperation during the investigation. 